\title{
The Experimental Vehicles Program Helps Advance the Mechatronics Engineering Program
}

\author{
Saeed D. Foroudastan \\ Middle Tennessee State University, Murfreesboro, Tennessee, 37132 USA
}

\begin{abstract}
Middle Tennessee State University (MTSU) started a Mechatronics Engineering program four years ago. Over those four years, enrollment has grown exponentially and has increased to over 400 students. One major factor that draws interest to this new program is the university's Experimental Vehicles Program (EVP), created by Dr. Saeed Foroudastan. The EVP includes different student teams that work to design and build the four projects the EVP has evolved to: human-powered lunar rover (formerly known as The Great Moonbuggy Race), powered off-road Baja, gasoline-powered formula car, and all-electric solar boat. These projects are designed to greatly enhance each student's classroom experience. The EVP provides students hands-on experience that allows them to apply what they have learned in the classroom to something in real life. The students are responsible for designing and building each project with their team, which also provides them with skills like effective communication, teamwork, project management and more. Each project also has a competition that members of the team normally travel to and are able to compete on an international level. The Mechatronics Engineering program and the EVP at MTSU are both providing truly great opportunities and preparing students well that wish to enter the engineering field after college.
\end{abstract}

Key words: Hands-on learning, engineering, mechatronics, project-based learning, EVP.

\section{Introduction}

The Experimental Vehicles Program (EVP) at Middle Tennessee State University (MTSU) gives students the chance to experience hands-on engineering opportunities before graduation. It was established in 2004 and grown each year, continuing to draw more and more interest. Students work on one of four teams to design and build one of the following projects: human-powered lunar rover, powered off-road Baja, gasoline-powered formula car, or all-electric solar boat. The EVP is available to every MTSU student, regardless of their major, but is a big factor in the growth of the Mechatronics Engineering program.

The Mechatronics Engineering program is a recent addition-fall 2013 semester-to the engineering department that has been extremely successful and already has over 400 students. Participating in the

Corresponding author: Saeed Foroudastan, Ph.D., professor and associate dean, research fields: engineering education, mechatronics, and modeling and simulation.
EVP, on top of having great classes within the program, provides a huge advantage to both the students in the mechatronics program and their future employers.

\section{Mechatronic Engineering Program}

Mechatronic engineering is the synergistic combination of precision mechanical engineering, electronic control and systems thinking in the design of products and manufacturing processes [1]. It is a specialized and growing field that is becoming a huge demand in the industry. MTSU launched its mechatronics program in August of 2013 and graduated its first class in May of 2016. The program has been extremely successful at MTSU. It now has over 400 students enrolled and over 60 graduates with plans for about 30 more this fall, most of them already receiving job offers by the time they graduate [2].

The mechatronics program offers preparation in diagnostics and design on integrated industrial automation systems as well as the various aspects of 


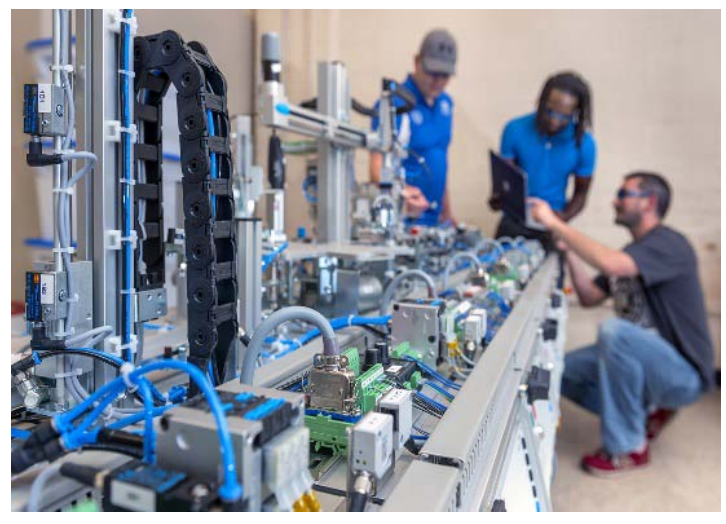

Fig. 1 Senior project presentation by students

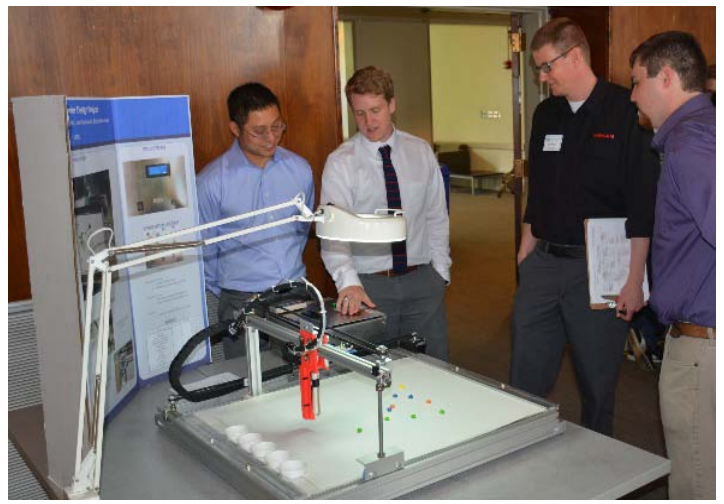

Fig. 2 Senior project presentation to industry by students

project and process management, systems engineering, and risk management [3]. MTSU has built a great curriculum and offers a great staff so that the students excel. Part of the curriculum is a senior project that gives the students hands-on experience, something MTSU strives to incorporate in this program (past examples shown in Figs. 1 and 2).

\section{Experimental Vehicles Program}

The EVP at MTSU began in 2004 and was started by Dr. Saeed Foroudastan. It is a student group on campus that is open to all majors. This group includes different teams to build and race different experimental vehicles they have designed. Since its beginning, the EVP has added some projects and dropped some projects to now include four options for students to choose from: the human-powered lunar rover (Fig. 3), powered off-road Baja (Fig. 4), gasoline-powered formula car (Fig. 5), or all-electric solar boat (Fig. 6).

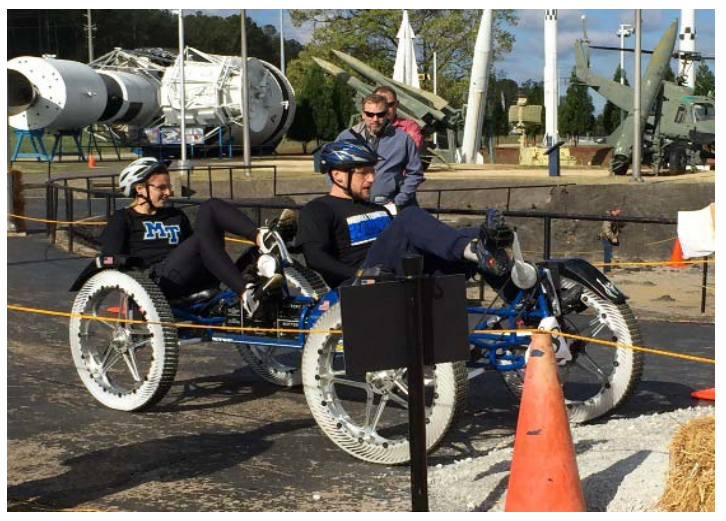

Fig. 32016 human exploration rover challenge

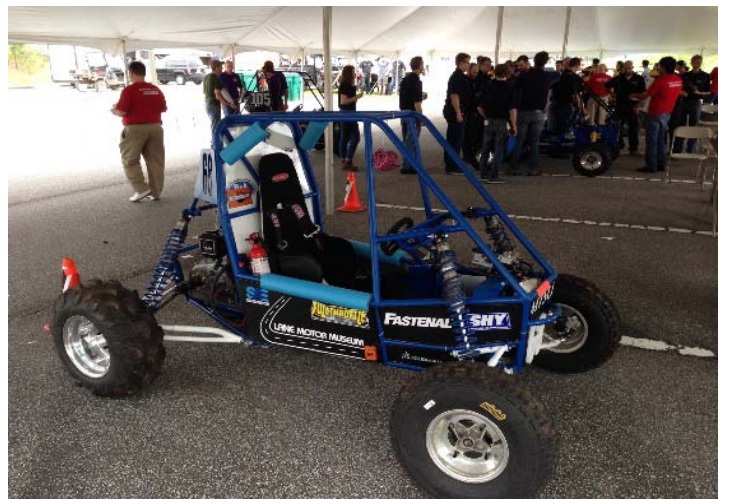

Fig. 4 MTSU SAE Baja at the competition

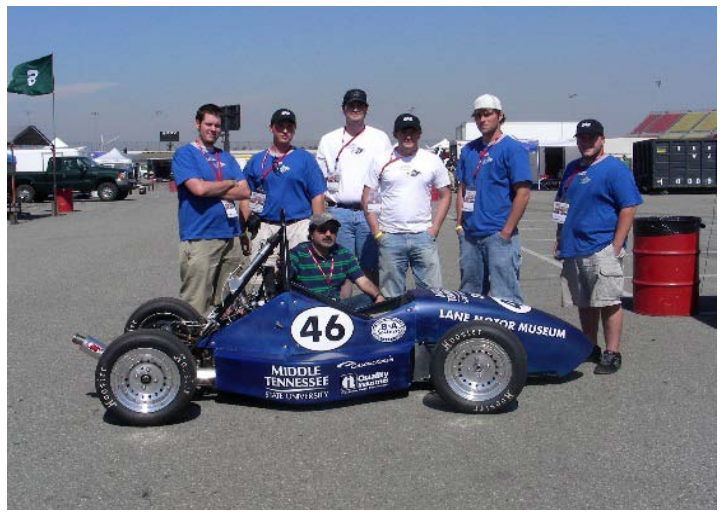

Fig. 5 MTSU team at SAE formula car competition

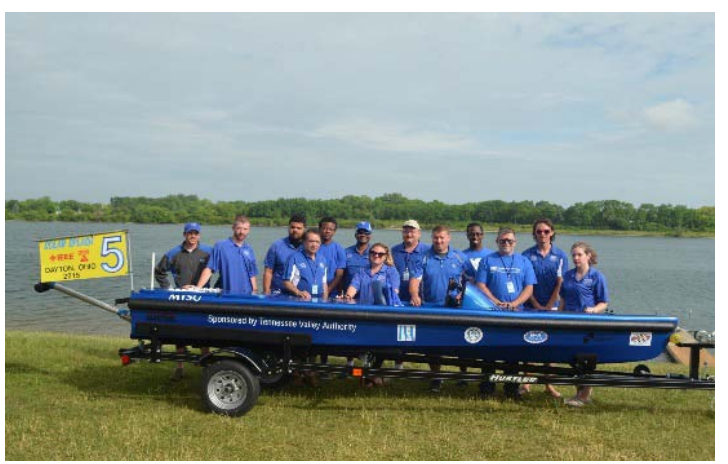

Fig. 6 MTSU team at the 2016 solar splash competition 
Each of the four projects provides its own unique challenges with strict guidelines the teams must follow. If students choose to be a part of the human-powered lunar rover team, they must design and build the vehicle to be able to be carried by two people, one male and one female, and the vehicle must be able to collapse into a five-foot cube. They then have the chance to race their rover on the track used to qualify the actual lunar rover. The students that choose to be on the powered off-road Baja team have to build their vehicle to survive rough terrain throughout a four-hour race and are judged based on eight different categories. Students who choose to be a part of the gasoline-powered formula car team work to make sure their vehicle meets the strict guidelines set by the Society of Automotive Engineers since they will go through an initial judging process before the race even begins. Those who choose to be on the all-electric solar boat team have to build a boat that is powered solely by batteries and a solar array. They then go on to compete in a five-day event being judged in multiple categories [4].

Students are able to join the EVP in the fall and work on the projects throughout the year until it is time for their respective competitions. While all the ideas come from the students, each team receives mentoring from staff and also from the EVP's many industry partners to help them perfect their ideas. The teams are also able to decide if they want to take the previous year's design and improve on it or completely start from scratch.

MTSU also has an S/STEM grant from the National Science Foundation that was awarded for $\$ 600,000$ to fund scholarships for mechatronics students. These students could receive stipends to work for the EVP.

\section{Advantages to Mechatronics Students}

The EVP provides a multitude of advantages to mechatronics students that are hard to incorporate in a classroom setting. As mentioned before, the mechatronics program really strives to incorporate hands-on projects. The EVP provides students the chance to greatly enhance their hands-on experience, and not just with building. It also provides many aspects that will give students a glimpse into what their job might look like after graduation. On top of being able to receive mentoring from the local industry partners the EVP provides, they are given guidelines to follow to create a project, working with a diverse team to achieve a common goal, and expected to meet deadlines. While doing this, students are gaining resume skills like communication, organization, time management, problem solving and more.

There are also leadership opportunities within the EVP. Like most student groups, there is a president, vice president, secretary, and treasurer. Each of the four teams also has its own captain. Natural leaders also emerge during this process as some students excel and are really able to guide others without any formal title.

The students in the EVP also devote so much time and effort to these projects that they normally form great friendships. The relationships are yet another advantage the EVP can bring. Students work together and help each other get through the rigorous classes and studies of the mechatronics program, often forming study groups or helping each other with tough assignments.

\section{Student Feedback}

Nicolas Cronin, an MTSU Mechatronics graduate, was able to reach the position of Lead Engineer at the Davis Groupe in Murfreesboro, TN, while still in school as a result of his work within the EVP. He describes his experience as follows: "I had been eyeing an engineering position at The Davis Groupe, where I was employed, and I wanted to be able to show them that I was good with electrical systems. By working on the solar boat team for two years and helping the team increase their performance each year I was a member, I was able to prove to my boss that I had what it took to be promoted to the position of Lead Engineer. While I no longer have the free time to commit to the EVP or the solar boat team, I'm grateful 
that I was able to work on the boat and use that work to prove my worth to my boss and advance to a position that I thought I would have to wait until I graduated to obtain.” [5]

\section{Conclusion}

The new Mechatronics Engineering program at MTSU is exceeding expectations and continuing to grow rapidly. The EVP does an excellent job at helping attract students to the program and also being a great asset to help those students who have already chosen mechatronics to get through the program. The two go hand in hand and provide students with unmatchable opportunities to be career ready once they graduate.

\section{References}

[1] Moheimani, S. O. R. "Mechatronics: The Science of Intelligent Machines.” An International Journal, https://www.journals.elsevier.com/mechatronics.

[2] "MTSU Graduates First Mechatronics Class." Daily News Journal, 2016.

[3] “Mechatronic Engineering, B. S.” Online MTSU Catalog, http://catalog.mtsu.edu/preview_program.php?catoid=13 \&poid=4101.

[4] Foroudastan, S., and Kelley, H. 2018. "Industry Partnerships Provide Students with Irreplaceable Opportunities at Middle Tennessee State University.” Presented at the 2018 ASEE Southeastern Section Conference Proceedings.

[5] Foroudastan, S., and Woodson, C. 2017. "How Solar Boating Teaches the Lessons of Energy Conversion and Conservation.” Presented at the 2017 ASEE Conference Proceedings. 